\title{
Taking care of the aged in Kenya: the changing trends
}

\section{Opinion}

It was a Thursday afternoon, on July 26 2007. A renowned Professor of Literature at the University of Nairobi (Kenya), and who at one time was a diplomat in South Africa, was presenting an inaugural lecture at the University entitled, the role and significance of oral literature in social and psychological development of children". One thing that Dr Kimamo has never forgotten is what transpired during the discussion session. A colleague, a Professor of Psychology, in the same university (Prof. Priscilla Kariuki) sparked an interesting debate. To quote a few of her words: The burden of caring for aging parents can be great. The family structure (in Kenya) has become more "top heavy" with more generations alive but fewer younger (family) members (available) as birth rates have declined. This means that more than one older family member is likely to need assistance but with fewer younger adults available (and perhaps willing) to provide it.....(Her memoirs, 2007).

Her contemporaries, whom Prof. Kariuki, referred to as the "sandwich generation" have been caught up between taking good care of their aging parents, but at the same time not neglecting their basic duty of taking good care of their own children, including educating them, amidst rising cost of basic, high school and university fees and the general cost of living. Yet after this struggle, there is no guarantee that their own children will take care of them.

A similar concern was noted by the famous Ugandan scholar and writer, Prof. Austin Bukenya in his newspaper article, "Will it be Nyumba ya Wazee (Home for the aged) for me?. ${ }^{1}$ Prof. Bukenya, who has taught languages, literature and drama at major East African universities, was preparing for his 72 birthday during this debate. In this article he notes that he has to decide between living with relatives and relocating to an old people's home. However, he regrets the negative perception associated with such homes, which is, people abandoned by their relatives and forced to depend entirely on charity. In his words,

In Africa, mention of going to an old people's home, or sending a relative there, is almost a taboo. It is taken as a rejection of your family if you consider going there, or a rejection by your family if they hint at the possibility of sending you there.... The two professor's concern is genuine considering what is happening in Kenya today. Homes for the aged have emerged, something that could not be fathomed in the past. In the traditional society, old people were highly respected and taking care of them was a noble duty. Old people were a central link to family members and on major public holidays like the Christmas day, children would converge at their elderly parent's or grandparent's home, carrying presents for them. In return, the elderly parents or grandparents would joyfully slaughter chicken or sheep or goats and share a meal with the large family. According to Achuka ${ }^{2}$ changing family values, rising cost of living and migration into cities or abroad has meant that many Kenyans are living away from parents and consequently unable to fulfill their traditional role of caring for them. This has given rise to old people's homes. Achuka has noted that the number in the capital city alone, Nairobi, has grown within a decade to more than 20 homes for elderly persons.

Kenya has about 1.5 million people aged over 60 years and this number is expected to rise to 2.5 million in the next 10 years. ${ }^{2}$ Two
Volume 3 Issue I - 2018

\author{
Charles Kimamo, Priscilla Kariuki \\ Department of Psychology, University of Nairobi, Kenya
}

Correspondence: Charles Kimamo, Senior Lecturer in the Department of Psychology, University of Nairobi, Kenya, Email conkimamo@yahoo.com

Received: October 01, 2017 | Published: January 04, 2018

categories of old people's homes exist in Kenya. Some are free for the occupants while others are paid. The paid ones range from about Ksh10, 000 (\$100) to as high as Ksh150, 000(\$1500) a month. The free ones are run by churches, notably the Presbyterian and the Catholic churches, and sometimes by the Government of Kenya through the City Commission. Both types of institutions paid or free, are unable to cope with the demand. Achuka gives an example of a home built in 1965 by the Presbyterian Church of East Africa and run by the Presbyterian Women Church Group usually referred to as "The Woman's Guild." Achuka observed that the waiting list is too long whether the homes are paid or not. When he visited a high cost one, charging up to Ksh $150,000(\$ 1500)$, the story was the same. It had a capacity of 30 and the only way those on the waiting list could get to be admitted was when an occupant died. Over 200 couples were on the waiting list.

The Nyumba ya Wazee that Prof. Bukenya was referring to is situated at the outskirts of the capital city, Nairobi, a place called Kasarani. This is where the famous Cardinal of the Catholic Church, Maurice Otunga (1923-2003), retired to, one of the reasons being that he did not want to be a burden to anyone. ${ }^{3}$

Cardinal Otunga joined the destitute elderly that had been accommodated there and requested to be treated like the rest of the group without special favors. Nyumba ya Wazee at Nairobi houses about 86 vulnerable elderly; both men and women of all nationalities and religions, most of whom are incapacitated and/or disabled, solely relying on the generosity and kindness of well-wishers for their sustenance. A similar Nyumba ya Wazee have been started in Mombasa City, at a place called Tudor. Nyumba ya Wazee is run by Catholic nuns referred to as," Little Sisters of the Poor". The Little Sisters of the Poor is a Roman Catholic religious institution for women. It was founded in 1839 by a nun called Saint Jeanne Jugan. Jugan established the institution to care for the elderly, having felt the need to care for the many impoverished elderly who lined the streets of French towns and cities. ${ }^{4}$

In Kenya, Little Sisters of the Poor depend on well- wishers to run the institution. When they run out of supplies, they will boldly stand at the entrance of supermarkets and request for donations to the home. They will usually list items required such as milk, sugar, rice, maize floor, yogurt, bread and cereals. Most people respond by buying whatever they can afford and donate it as they leave the supermarket. Mother Teresa's Missionaries of Charity, another wing of the catholic nuns, also run an old people's home in Nairobi's Mukuru slums and depend on well-wishers to support their course. 
The Government of Kenya started a programme to cater for needy elderly persons. "The Older Persons Cash Transfer (OPCT) programme" as it is officially referred to in Kenya or "Pesa ya Wazee" (Money for the elderly) by laymen, was started in 2007. It is funded by the Government of Kenya. The programme focuses on providing cash transfer to poor households who have at least one member above the age of 65 years. In the Financial Year 2015/2016, the total number of beneficiaries was $325,000 .{ }^{5}$ Plans are underway to ensure that by the beginning of January 2018, all persons above the age of 70 years will receive a cash transfer in the form of a monthly stipend and National Hospital Insurance Fund (NHIF) cover that will be paid by the Government. ${ }^{6}$ Currently, those over 70 years of age receive a stipend of Ksh 2000 (\$200) a month. This may not be adequate but it is certainly a move in the right direction.

From the above, it can be inferred that values on the care of the elderly in a family are changing in Kenya, with more households focusing on the nuclear family, leading to the neglect of the elderly. This is giving birth to destitute elderly who, if no intervention is put in place, will die of neglect. The government of Kenya is teaming up with homes for the poor to ensure that the elderly poor in Kenya are not neglected. Some public homes for the poor are in bad shape in terms of accommodation facilities yet an elderly person being in such a home is seen as a better evil than being neglected at home. Some even report that it is a better life, in the old people's home, because of having people of their age around them to talk to and socialize with $^{7,8}$ instead of living a lonely neglected life in the village.

\section{Acknowledgements}

None.

\section{Conflict of interest}

Authors declare that there are no conflicts of interest.

\section{References}

1. http://www.nation.co.ke/lifestyle/weekend/Will-it-be-home-or-nyumbaya-wazee-for-me/1220-3053870-s0pwa7/index.html

2. http://www.nation.co.ke/lifestyle/lifestyle/The-new-age-dilemma-ofcaring-for-ageing-parents/1214-3203774-au5biyz/index.html

3. http://www.cardinalotunga.org/index.php/ct-menu-item-1

4. https://en.wikipedia.org/wiki/Little_Sisters_of_the_Poor\#cite_noteOSV1-1

5. http://www.labour.go.ke/social-welfare.html

6. Olive B. Universal social welfare for those over 70 meant to foster inclusivity-PS, Kenya; 2017.

7. http://erepository.uonbi.ac.ke/handle/11295/62271

8. http://www.capitalfm.co.ke/news/2017/03/universal-social-welfare-forthose-over-70-meant-to-foster-inclusivity-ps/ 